\title{
THE IMPACT OF COVID-19 ON THE INSURANCE INDUSTRY OF BANGLADESH
}

\author{
Anamul Haque \\ Assistant Professor \\ Department of Banking and Insurance \\ University of Chittagong, Bangladesh \\ E-mail: anam.haq@cu.ac.bd \\ Nishat Taslin Mohona \\ Undergraduate Student \\ Department of Banking and Insurance \\ University of Chittagong, Bangladesh \\ E-mail: nishatmohona06@gmail.com \\ Sabrin Sultana \\ Undergraduate Student \\ Department of Banking and Insurance \\ University of Chittagong, Bangladesh \\ E-mail: sabrinsultana1060@gmail.com \\ Umme Kulsum \\ Undergraduate Student \\ Department of Banking and Insurance \\ University of Chittagong, Bangladesh \\ E-mail: ummekulsum.ctg2018@gmail.com
}

\begin{abstract}
This study investigates the impact of Covid-19 on the insurance industry of Bangladesh. We utilize a quarterly panel data of top-performing both life and non-life companies for the duration between Q1:2018 to Q1:2021. We depend on the quantitative method to determine the exact scenario implementing through the fixed effect model. The finding explains that the adverse effect of the pandemic is significant on the quarterly premium income, insurance density, and penetration. A robustness test further justifies the validity of the findings. We discuss the causes behind decline to portraits real scenario of such harsh impact. The sector demands potential measures that ensure a stable situation.
\end{abstract}

Keywords: Covid-19, Lockdown, Insurance Industry of Bangladesh.

JEL Classification Codes: G22, I18, I19. 


\section{INTRODUCTION}

The mass global tension and challenge nowhere is the SARS-CoV2 (Covid-19), a highly contagious infection with acute death cases, was first identified in Wuhan city, Hubei province, China, in December 2019 (Shi et al., 2020). By the end of January 2020, it was declared public health emergency by the World Health Organization (WHO). It has been annunciated and attained a pandemic status on March 11th, 2020. However, in the meantime, it had spread across 215 territories and countries on all five continents (Wang et al., 2020). The countries like the USA, Brazil, India, UK, and Spain have experienced peak cases and deaths. As of June 2021, (WHO, 2021) reports there have been more than 175 million confirmed cases of Covid-19, including over 3.8 million deaths, which is one of the deadliest pandemics in the world's history.

South Asia is gradually joining the ranks of Covid-19-affected countries, with the first verified Covid-19 case in this region as reported on January 24th in Nepal by a Nepalese student who had recently returned from China (Chalise, 2020). On January 27th and January 30th, respectively, Sri Lanka and India announced the first confirmed COVID-19 cases. The cumulative number of Covid-19 cases in South Asia was 3,649 on April 1st, up to 62,895 on May 1st, and above 200,000 on May 21st. SAARC (2020) reports that the total deaths soared from 71 on April 1st to 1,772 on May 1st and about 5,000 on May 21st. According to IEDCR (Institute of Epidemiology, Disease Control, and Research) in Bangladesh, the first Covid-19 confirmed cases dug out on March 8th, 2020. The USA Embassy in Dhaka had identified Bangladesh as one of the most 25 vulnerable countries affected by the epidemic, with a high risk of spreading in March. On March 26th, the government imposed a general lockdown for the first time extended till May. Afterward, concerning the economic impact in the developing economy like Bangladesh, the lockdown has been eased. Till now, Covid-19 cases in Bangladesh are showing up more than 8 lakhs, and deaths are 13 thousand.

This pandemic has exposed a catastrophic result in the world economy due to preventive measures like social distancing, lockdown, counteracting travel compliance with the acute health crisis (Kleinberg et al., 2020). (Khan et al., 2020)) Addressed that the recession has crashed the world economy by the increment of business shutdown and unemployment problem. Further, different sectoral shocks like manufacturing, services, trade, and tourism are also the worst sufferer of the world economy (Feyisa, 2020). It has already resulted in various economic and social disruptions leading to a decline in services, investment, industrial production activities, and worldwide consumption (Wang et al., 2020). During this pandemic, non-performing loans have exceeded, causes additional credit risks over financial sectors (Ozili \& Arun, 2020). The global financial market and the particular stock market have faced enormous economic shocks (Zhang et al., 2020). The Covid-19 has a catastrophic effect on developed economies. For example, the unemployment rate in the USA has risen to a record 14.7\%, with more than 20 million jobs lost, and GDP dropped by $4.8 \%$ in the very first quarter of 2020 (Hutt, 2020). For an emerging economy like China, the sealing airport and close contact with them have caused a $2 \%$ decline in Chinese economic growth. As China dominates $16 \%$ of the world's economic activities, any disruption to the Chinese economy also hits the world economy (Fernandes, 2020). The shutdown directly affected the developing economy's real output and overall sectors indirectly (Khurshid \& Khan, 2021). The reduction of raw material export, a steep decline in remittance, and costly access to the international market worsen the situation for developing countries (Loayza \& Pennings, 2020). While developed economies responded through direct transfer and regular social insurance payments to their workers suffered by lockdown, the developing economy cannot respond immediately due to the lack of fiscal capacity, broad informal sectors, and a greater purview of intergenerational households (Alon et al., 2020). In this situation, the lack of adequate policy may lead to recession and even depression in the long run (Khurshid \& Khan, 2021). 
A developing country like Bangladesh is undergoing tremendous economic trouble in international and domestic demands because of the coronavirus outbreak and lockdown. The spread of the coronavirus tremendously affected Bangladesh's economies and financial sectors. By inhibiting the pandemic's first wave by implementing social distancing, pandemic protocol, and vaccination, the second wave of COVID-19 hit back again, and the country had to go through partial lockdown repeatedly. The partial lockdown extended economic burden, socio-economics insecurity (Bodrud-Doza et al., 2020). With the rise of unemployment, poverty, remittances, healthcare crisis, quality education, and downward slope of RMG export, Bangladesh might experience stand back its Sustainable Development Goals (SDG) (Shammi et al., 2020). Furthermore, downfall in the oil prices and depressed demand, the remittance flow of Bangladesh represents a negative outward as Bangladesh's GDP constitutes 7\% of international remittances (Aneja \& Islam, 2020). Moreover, due to travel restrictions, the tourism industry in Bangladesh observed an adverse effect because of losing revenue (Deb \& Nafi, 2020). Governments and financial institutions seek an escape from total annihilation, leading to cast new hope from the insurance industry. The government promulgated various financial packages of about USD 11.90 billion (Islam et al., 2020), though the global uncertainty shocks remarkably and hit Bangladesh's economy through increasing economic challenges exponentially in the agriculture, industry, and service sectors (Ahmed, 2021; Begum et al., 2020).

The scope of this study is the insurance industry. The insurance market of Bangladesh is exposed to an adverse condition as the COVID-19 outbreak, which still exists in Bangladesh. Insurance Development and Regulatory Authority (IDRA) reports both the life and non-life insurance companies' growth rate of gross premium from the first quarter of 2020 to the second quarter of 2020 was $-20.42 \%$; shows a sharp drop in growth. Maximum non-life insurance policies, such as fire insurance, marine (cargo) insurance, motor insurance, miscellaneous insurance, faced negative growth rates of gross premium. Our study showcases the present condition of the insurance industry in Bangladesh during the pandemic. Without the well-being of insurance companies, the pandemic seems to have a catastrophic effect on the whole economic sector. Therefore, this economy will not be able to overcome the crisis to make genuine progress. Thus, assuredly, this is of practical and policy value for exploring how the Covid19 pandemic influences the insurance market of Bangladesh. Furthermore, this study can enrich to the insurance industry professionals because almost no study has been conducted yet in this subject matter. An empirical investigation examines the impact of Covid-19 on insurance in China reveals a negative impact in the short term (Wang et al., 2020). Motivated from the study, an attempt has made to mitigate the research gap and illustrate the impact of Covid-19 on the Bangladesh insurance industry. Therefore, the study endeavored to understand the consequence of Covid-19 influence on the insurance sector in Bangladesh.

Data includes the total 20 top life and non-life insurance companies based on their premium income for the years 2018, 2019, 2020, and the first quarter of 2021. Through mean-variance tests and panel data regression, we find that Covid-19 results in a decrease in the quarterly premium growth. Here, we contribute the body of knowledge to determine the effect of the Covid-19 crisis on Bangladesh's insurance industry, including how insurance elements react to such incidents. This study sought to explore the way crisis can break potential and well-established market's natural tone. This research benefits the policymaker and insurance professionals to exercise crucial decisions regarding stable insurance industry, and stakeholders to prioritize safety and security.

The following is how the rest of the article is structured: Section 2 introduces the data, econometric model and defines the variables. Then, section 3 reports the results and discusses the empirical findings. Moreover, the final section wraps up the research. 


\section{LITERATURE REVIEW}

Insurance is considered an innovative risk financing technique to protect the best interests of risk-averse individuals (Cummins \& Barrieu, 2013; Spence \& Zeckhaser, 1978; Outreville, 1998; Schoemaker \& Kunreuther, 1979). The purposes of underlying insurance demand are contingency mutually exclusive and jointly exhaustive consumption opportunities (Ehrlich \& Becker, 1972). The development of the insurance industry is highly correlated with economic growth (Ćurak et al., 2009 ; Devarakonda, 2016). The insurance industry contributes a vital role by steering and promoting investment and savings in a particular economy (Gupta, et al., 2014). It is challenging for businesses to encounter all the risks and uncertainties (Ahmed et al., 2011). That is why the profitability and solvability of insurance companies matter the most to have a stabilized economy (Kripa \& Ajasllari, 2016). An individual gets relief from possible adverse and uncertain events outcome of activity through insurance. Overall, insurance facilities reduce risk and benefit personal and domestic security (Uddin et al., 2014). The appearance of the pandemic causes numerous unexpected situations and shocks like liquidity problems, portfolio risk, reliance on reinsurance, asset crisis and protection risk, etc. (Babuna et al., 2020). (Larson \& Sinclair, 2021) found that in the current Covid-19 pandemic, unemployment insurance claims have jumped significantly.

Among the European countries, the insurance industry demonstrated a disruptive negative impact during the Covid-19 outbreak due to imbalances in the number of claims with the capital and solvency stability (Puławska, 2021). This region also reports a reduction in the Return on Asset (ROA) among the German and Italian insurance companies; the solvency ratio in the Belgian, French, and German insurance industries. Despite the significant financial losses produced by Covid, the insurance industry was not adequately prepared to deal with the losses (Levantesi \& Piscopo, 2020). Similarly, (Farooq et al., 2021) conducted a study on Australia, Canada, Germany, the USA, UK, Brazil, India, and Indonesia found Covid-19's negative effect on the stock returns both in the short and long terms on insurance firms. Other studies like; (Kirti \& Shin, 2020) alarmed that this pandemic will keep impacting insurers directly and indirectly via health shocks such as an increase in mortality and morbidity and indirectly via financial shocks, which are higher credit spreads, lower equity prices, and widespread downgrades. For example, considering the global situation, there has already been a predicted downslope in property insurance, cargo insurance, life insurance (Zhang et al., 2020).

The developing economies have also experienced the adverse impact of this epidemic on investment amount and income of the commercial insurance companies due to having a great influence on the expenditure (Xia et al., 2020). In this regard, studies (e.g., Ye et al., 2021) suggest similar results. Chinese insurance industry reveals that the stock prices dropped overall in the initial quarter. Also, it exposes that the increase of Covid-19 cases decreases the gross commercial insurance premium, insurance density, and insurance depth among the Chinese insurers. The overall significant downwards spiral has been witnessed in the industry in the short term (Wang et al., 2020) after considering insurance density and depth, especially the personal insurance. The industry has witnessed similar losses in North Macedonia (Stojkoski et al., 2020), Ethiopia (Worku \& Mersha, 2020), Ghana (Babuna et al., 2020), and India (Parvathi \& Lalitha, 2021). In the South Asia, till the end of 2020 the Covid-19 impact was not adverse in India. Moreover, the impact of Covid-19 on life insurance companies is positive. This is evident by (Ramasamy, 2020) who found that insurance companies are attracting more customers and gaining profits during this Covid-19 situation because people are scared and wanted to obstruct the financial crisis if they are affected by the aforesaid pandemic.

Undoubtedly, the Covid-19 pandemic has created an unexpected and extensive economic shock among the insurance companies in every economy. However, no empirical research has been done on the impact of the epidemic on Bangladesh's insurance industry. As a result, the study aims to determine the 
impact of Covid-19 on the insurance industry in Bangladesh. We hypothesize that there is a significant impact of Covid-19 in the Bangladeshi insurance industry.

\section{Variables and Sample}

\section{DATA AND METHODS}

This study utilizes the hand-collected data of the top 20 life and non-life insurance companies in Bangladesh. The top performers have been listed based on their premium income. To illustrate the effect of the Covid-19, we collect our panel data quarterly for the years 2018, 2019, 2020, and the first quarter of 2021 based on the data availability. Though the outbreak hits the country in March 2020, due to the disruption of the global economy, the impact has started affecting the economy from the beginning of 2020. Here, the years 2018 and 2019 are considered to be before the pandemic, and the year 2020 and 2021 are considered during the pandemic situation. Table-1 portraits the independent variable, dependent variables, and control variables with descriptions and data sources used in this study.

Table 1. Description of Variables

\begin{tabular}{|c|c|c|c|}
\hline Variables & Variable name & Description & Data Sources \\
\hline \multicolumn{4}{|c|}{ Independent variable } \\
\hline & $\begin{array}{l}\text { Covid_Dummy } \\
\text { (C_Dummy) }\end{array}$ & $\begin{array}{l}0 \text { for the non-Covid- } \\
19 \text { situation and } 1 \text { for } \\
\text { the Covid-19 } \\
\text { situation }\end{array}$ & \multirow{2}{*}{$\begin{array}{l}\text { Official website of IEDCR } \\
\text { (Institute of Epidemiology, } \\
\text { Disease Control, and } \\
\text { Research) }\end{array}$} \\
\hline & $\begin{array}{l}\text { Confirmed Covid-19 } \\
\text { cases (QCASES) }\end{array}$ & $\begin{array}{l}\text { The log of total } \\
\text { number of confirmed } \\
\text { cases per quarter }\end{array}$ & \\
\hline \multicolumn{4}{|c|}{ Dependent variable } \\
\hline & $\begin{array}{l}\text { Quarterly premium } \\
\text { growth (QPG) }\end{array}$ & $\begin{array}{lr}\text { Gross } & \text { premium } \\
\text { income } & \text { growth } \\
\text { generated } & \text { per } \\
\text { quarterly } & \\
\end{array}$ & \multirow{3}{*}{$\begin{array}{l}\text { Official website of IDRA } \\
\text { (Insurance Development \& } \\
\text { Regulatory Authority) }\end{array}$} \\
\hline & $\begin{array}{l}\text { Insurance density } \\
\text { (INSD) }\end{array}$ & $\begin{array}{l}\text { The ratio of gross } \\
\text { premium } \\
\text { population }\end{array}$ & \\
\hline & $\begin{array}{l}\text { Insurance } \\
\text { penetration (INSP) }\end{array}$ & $\begin{array}{l}\text { The ratio of gross } \\
\text { premium to GDP }\end{array}$ & \\
\hline \multicolumn{4}{|c|}{ Control variable } \\
\hline & $\begin{array}{l}\text { Consumer } \\
\text { index }(\mathrm{CPI})\end{array}$ & $\begin{array}{l}\text { Quarterly CPI (using } \\
\text { the base year 2005- } \\
2006 \text { ) }\end{array}$ & \multirow[t]{2}{*}{$\begin{array}{l}\text { Official website of BBS } \\
\text { (Bangladesh Bureau of } \\
\text { Statistics) }\end{array}$} \\
\hline & $\begin{array}{l}\text { Producer price index } \\
(\mathrm{PPI})\end{array}$ & $\begin{array}{l}\text { Quarterly PPI (using } \\
\text { the base year 2005- } \\
2006 \text { ) }\end{array}$ & \\
\hline
\end{tabular}




\begin{tabular}{|l|l|l|l|}
\hline $\begin{array}{l}\text { Per capita gross } \\
\text { domestic product } \\
\text { (lGDP) }\end{array}$ & $\begin{array}{l}\text { The logarithm of } \\
\text { quarterly per capita } \\
\text { GDP }\end{array}$ \\
\hline
\end{tabular}

\section{Econometric Model}

Consistent with (Wang et al., 2020), we develop the following fixed-effects econometric model to estimate the Covid-19 impact on the insurance industry of Bangladesh.

$$
Q P G_{i t}=\alpha_{0}+\alpha_{1} \text { COVID Dummy }+\alpha_{2} \text { CPI }_{t}+\alpha_{3} P P I_{t}+\alpha_{4} G D P t_{t}+\eta \mathrm{t}+\varepsilon \mathrm{t}
$$

Where QPGit represents the overall firm-level quarterly premium growth at a given fixed time. Apart from this QPG, insurance density (INSD), and penetration (INSP) are also used as the performance indicators of the insurance industry of Bangladesh in subsequent models. COVID_dummy is a dummy variable where 0 indicates the non-Covid-19 situation and 1 indicates the Covid-19 situation, valued in time margin. CPIt, PPIt, lGDPt are the economic variables that have considerable influence over the dependent variables. The subscript $i$ denotes the insurance firms, and $t$ refers to the time from January 2018 to March 2021, and the $\eta t$, gt report as the time fixed effects and the error term. For the robustness test, we modified the equation to explore the significance of the pandemic on the Bangladeshi insurance market through developing an alternative independent variable $\mathrm{nCoVt}$, which stands for the log of the number of confirmed Covid-19 cases to measure the pandemic intensity given a period.

\section{Summary Statistics}

The Covid-19 has a catastrophic impact on the Bangladesh economy in various dimensions due to pandemic protocols like lockdown, social distancing, and economies shut down. Here, Table-2 exhibits the summary statistics of the explained variables (quarterly premium growth, insurance density, and penetration), the explanatory variable (quarterly Covid-19cases, Covid-19_Dummy), and the control variable (CPI, PPI, lGDP). Since there are no other studies in such a type, therefore we failed to compare the summary statistics with any other researchers.

Table 2. Summary Statistics

\begin{tabular}{|l|l|l|l|l|l|}
\hline \multicolumn{9}{|c|}{} \\
\hline Variable & Observation & Mean & Std. Dev. & Min & Max \\
\hline QPG & 260 & -0.4127967 & 3.280285 & -5.26316 & 1.960784 \\
\hline INSD & 260 & 753.9231 & 64.58476 & 664 & 824 \\
\hline INSP & 260 & 0.5453846 & 64.58476 & 0.49 & 0.57 \\
\hline QCASES & 260 & 841.9231 & 1478.556 & 0 & 4355 \\
\hline lGDP & 260 & 6.152011 & 0.059413 & 6.037274 & 6.200408 \\
\hline CPI & 260 & 267.66 & 13.46967 & 247.02 & 290.76 \\
\hline PPI & 260 & 221.9654 & 2.109232 & 220.32 & 226.33 \\
\hline C-Dummy & 260 & 0.3076923 & 0.4624286 & 0 & 1 \\
\hline
\end{tabular}

\section{Results}

We start with the simple mean-variance test to compare the insurance industry position of Bangladesh between prior and posterior to the Covid-19 pandemic. Then, Table 3 reports the mean-variance test of quarterly premium growth, insurance density, and insurance penetration before the pandemic and during 
the pandemic. Results show that the mean difference between prior and posterior to the Covid-19 pandemic of Bangladesh industry is statistically significant. The findings are consistent with (Wang et al., 2020), who also observed the Covid-19 pandemic's impact on the Chinese insurance market. Therefore, we can interpret that Covid-19 results in a decrease in quarterly premium growth. There is no significant effect on insurance density in Bangladesh during the covid-19 pandemic because people may have more insurance policies concerning their health and property. However, a significant difference is shown in the table between the mean-value of insurance penetration which tells us that there is a negative impact on the overall development of the insurance industry during the pandemic.

Table 4 reports the baseline regression results, which reflect that COVID-19 has a significant negative impact on the insurance industry of Bangladesh in terms of premium growth, insurance density, and penetration. The coefficients results are robust and economically significant as well. The controls have expected signs too. The results are consistent with other studies (e.g., Wang et al., 2020) that indicate that the financial ramifications of the Covid-19 pandemic affect Bangladesh's general economic activity, resulting in a drop in income and incur a high household medical cost. Also, in Bangladesh, insurance is a last-resort financial decision after paying for all kinds of household expenditures (Werner, 2009). During this pandemic, people face unexpected income loss and higher medical expenses; therefore, the insurance sector faces a severe income loss. In addition, the disruption in overall business activity worsens the situation for most non-life insurance companies.

In addition, as a part of the robustness check, we do an alternative measurement of the Covid-19 pandemic crisis that has been reported in table-5. We develop a continuous variable based on the log of quarterly confirmed cases reported in Bangladesh. It is observed that the quarterly premium growth, insurance density, and penetration, all certain variables, have experienced a significant reduction during the Covid-19. The robust check carried using quarterly data from January 2018 to March 2021. Here, the coefficient of quarterly gross premium and quarterly confirm Covid-19 cases reveals significant influence. The rising number of covid-19 cases has a quantitatively significant adverse effect on premium growth, insurance density. Table-5 displays Covid-19 negative effects on the gross premium of the Bangladeshi insurance market. By each unit increase of Covid-19 confirm case droops 4.912 percent of the premium. Furthermore, insurance density adversely causes by the rise of Covid-19, each confirmed case by BDT .0168 million losses. Insurance penetration negatively accelerated by every upward move in quarterly confirm Covid-19 cases by .0132 percent. Overall, Covid-19 contrarily hit quarterly premium growth, insurance density, and insurance penetration. The drastic Covid-19 force is demoting insurance market harmony over the pandemic period.

Table 3. Mean-variance tests

\begin{tabular}{|l|l|l|l|l|l|l|l|l|l|}
\hline & \multicolumn{5}{|c|}{ Prior to the Pandemic } & \multicolumn{3}{c|}{ During the Pandemic } & \multicolumn{1}{c|}{ T-test } \\
\hline & Obs & Mean & $\begin{array}{l}\text { Std. } \\
\text { Err. }\end{array}$ & $\begin{array}{l}\text { Std. } \\
\text { Dev. }\end{array}$ & Obs & Mean & $\begin{array}{l}\text { Std. } \\
\text { Err. }\end{array}$ & $\begin{array}{l}\text { Std. } \\
\text { Dev. }\end{array}$ & Mean Difference \\
\hline $\begin{array}{l}\text { Quarterly } \\
\text { Premium } \\
\text { Growth }\end{array}$ & 180 & 1.743 & 0.046 & 0.618 & 80 & -5.263 & 0 & 0 & $-7.006 * * *$ \\
\hline $\begin{array}{l}\text { Insurance } \\
\text { Density }\end{array}$ & 180 & 747.555 & 5.699 & 76.304 & 80 & 768.25 & 1.510 & 13.508 & $20.694^{* * *}$ \\
\hline $\begin{array}{l}\text { Insurance } \\
\text { Penetration }\end{array}$ & 180 & 0.560 & 0.001 & 0.015 & 80 & 0.5125 & 0.001 & 0.013 & $-.048^{* * *}$ \\
\hline Note: The symbols $* * *, * *$, and * represent significance levels of $1 \%, 5 \%$, and $10 \%$, respectively. \\
\hline
\end{tabular}


Table 4. Baseline Regression

\begin{tabular}{|l|c|c|c|}
\hline & Model 1 & Model 2 & Model 3 \\
\hline & QPG & INSD & INSP \\
\hline C-Dummy & $-6.986664 * *$ & $-81.26438 * * *$ & $-0.009292^{* * *}$ \\
\hline CPI & .1261954 & 13.76703 & .0024771 \\
\hline & $-0.0238834 * * *$ & $2.644873 * * *$ & $-0.0023557 * * *$ \\
\hline PPI & .0071859 & .7839297 & .0001411 \\
\hline & $-0.065095^{* * *}$ & $4.479256 * * *$ & $-0.0001096^{* * *}$ \\
\hline lGDP & .020187 & 2.202254 & .0003963 \\
\hline & $10.23456 * * *$ & $413.8841 * * *$ & $0.2139321 * * *$ \\
\hline Quarterly FE & 1.33061 & 145.1602 & .0261186 \\
\hline N & Y & Y & Y \\
\hline Overall R sq- & 260 & 260 & 0.9039 \\
\hline Note: The symbols $* * *, * *$, and $*$ represent significance levels of $1 \%, 5 \%$, and $10 \%$, respectively. \\
\hline
\end{tabular}

Table 5. Robustness Check

\begin{tabular}{|c|c|c|c|}
\hline & Model 1 & Model 2 & Model 3 \\
\hline & QPG & INSD & INSP \\
\hline QCASES & $-.0013715 * * *$ & $-.0167691 * * *$ & $-0.00000487 * *$ \\
\hline CPI & .0000535 & .0030637 & $4.65 \mathrm{e}-07$ \\
\hline & $-.1262271 * * *$ & $1.576169 * * *$ & $-.0020384 * *$ \\
\hline PPI & .0118746 & .6799259 & .0001031 \\
\hline & $-.7972185 * * *$ & $-4.111605 * * *$ & $-.001364 * * *$ \\
\hline GGP & .0329888 & 1.888896 & .0002864 \\
\hline & $33.87509 * * *$ & $675.3449 * * *$ & $.1950288 * * *$ \\
\hline Quarterly FE & 2.177175 & 124.6622 & Y \\
\hline N & Y & Y & 260 \\
\hline Overall R-sq & 260 & 260 & 0.9305 \\
\hline Note: The symbols $* * * * *$ and $*$ represent significance levels of $1 \%, 5 \%$, and $10 \%$, respectively.
\end{tabular}

Note: The symbols ***,**, and * represent significance levels of 1\%, 5\%, and 10\%, respectively.

\section{Discussion}

We observe that all dependent variables experience negative effects during the Covid-19 pandemic. There are a variety of explanations for such events. Among them, first of all, insurers face a shortage of liquidity, portfolio risk, and reinsurance protection during this pandemic. In addition, social distancing and containment measures limit the general communication of people. Thus, commercial activity is reduced. Furthermore, due to several episodes of congestion, all kinds of economic activities have come to a halt, negatively affecting all international trade, tourism, hotels, and limited infrastructure, in as many industries that depend on these sectors are also important related to premium growth (Dev \& Sengupta, 2020). In addition, businesses have faced many crises, including order cancellations and travel restrictions (Salehnia et al., 2020). Thus, the impact on new insurance sales is determined to be reduced. On the other hand, the crisis has hit a number of insurers who suffered extremely serious complications during Covid- 
19 due to declining premium collections and increasing claims. Liquidity is considered to be an important factor related to insurance. As a result, massive claims attacks on cash reserves create an uncomfortable state in insurance companies (Acharya \& Steffen, 2020).

At the household level, the number of new car purchases decreased as all stores were restricted from opening. Auto insurance fell on because of no limited-time motor vehicle sales, indicating a dramatic drop in auto insurance coverage. New trends and coverage are dwindling. The travel ban prevented potential new buyers from enforcing the travel policy (Salehnia et al., 2020). Because, paying without specific consequences seems trivial. Furthermore, even before the pandemic as a developing country with financial constraints, most Bangladeshis were not interested in having a general insurance policy (Werner, 2009). The situation is also worsening as the operations of companies have been closed for several days, leading to unemployment and low income, which explains a negative result of insurance density.

Although penetration is not enough, Bangladesh has great potential in the insurance sector due to stable GDP growth. However, this pandemic has hampered strength due to rising unemployment, declining purchasing power, and per capita income (Ahamed, 2021). This ultimately leads to negative growth in insurance penetration. While there is the prospect of an explosive health insurance penetration rate during the outbreak, the lack of a marketing, awareness, and digitalization strategy will limit the likelihood of contracting the disease.

\section{CONCLUSION}

The global impact of government-ordered business closures to contain the Covid-19 outbreak has been enormous, resulting in different economic variations. Therefore, social aspects regarding pandemic mitigation, household spending, and consumption are all being considered in relation to Covid-19 research. However, few empirical studies have been conducted on the impact of the epidemic on the insurance market in developing countries such as Bangladesh. In this regard, this study aims to contribute to the growing literature on the impact of Covid-19 on the Bangladesh insurance industry using companylevel panel data and fixed-effects models. By comparing Covid-19 and non-Covid-19 states, the results show that this pandemic has a significant contribution to the contraction of the insurance sector. The regression models also signal a negative impact of the Covid-19 pandemic on Bangladesh's insurance industry. This short-term negative impact is reflected in premium growth, insurance density, and insurance penetration. The results were statistically significant and robust compared with other measures. This study has certain limitations that should be noted. It is difficult to understand the impact of the pandemic on the insurance market in Bangladesh due to the lack of sample size, recent data, and time constraints. The researchers continued to work by developing large panel data and looking at longer time periods. We also hope that future researchers will tackle the channels of the Covid-19 pandemic causing misery for insurance companies. However, while talking about management effects, this research will allow decision-makers and managers to understand the risk they are exposed to when taking out an insurance contract.

\section{REFERENCES}

Acharya, V., \& Steffen, S. (2020). Stress tests' for banks as liquidity insurers in a time of COVID. VoxEU. org, March, 22.

Ahamed, F. (2021). Macroeconomic impact of Covid-19: A case study on Bangladesh. IOSR Journal of Economics and Finance (IOSR-JEF), 12(1), 24-29. 
Ahmed, N., Ahmed, Z., \& Ahmad, U. (2011). Determinants of Performance: A Case of Life Insurance Sector of Pakistan. International Research Journal of Finance and Economics, 61(1), 123-128.

Alon, T., Kim, M., Lagakos, D., \& VanVure, M. (2020). How Should Policy Responses to the COVID19 Pandemic Differ in the Developing World? (No. w27273). National Bureau of Economic Research.

Aneja, A., \& Islam, S. T. (2020). Bangladesh faces a crisis in remittances amid COVID-19. World Economic Forum.

Babuna, P., Yang, X., Gyilbag, A., Awudi, D. A., Ngmenbelle, D., \& Bian, D. (2020). The impact of Covid-19 on the insurance industry. International Journal of Environmental Research and Public Health, 17(16), 5766.

Begum, M., Farid, M. S., Alam, M. J., \& Barua, S. (2020). COVID-19 and Bangladesh: Socio Economic Analysis towards the Future Correspondence. Asian Journal of Agricultural Extension, Economics \& Sociology, 38(9), 143-155. https://doi.org/10.9734/ajaees/2020/v38i930417

Bodrud-Doza, M., Shammi, M., Bahlman, L., Islam, A. R. M., \& Rahman, M. (2020). Psychosocial and socio-economic crisis in Bangladesh due to COVID-19 pandemic: a perception-based assessment. Frontiers in public health, 8, 341.

Chalise, H. N. (2020). South Asia is more vulnerable to COVID-19 pandemic. Archives of Psychiatry and Mental Health, 4(1), 046-047. https://doi.org/10.29328/journal.apmh.1001018

Cummins, J. D., \& Barrieu, P. (2013). Innovations in Insurance Markets: Hybrid and Securitized RiskTransfer Solutions Handbook of insurance (pp. 547-602). Springer. https://doi.org/10.1007/978-14614-0155-1_20

Ćurak, M., Lončar, S., \& Poposki, K. (2009). Insurance sector development and economic growth in transition countries. International Research Journal of Finance and Economics, 34(3), 29-41.

Deb, S. K., \& Nafi, S. M. (2020). Impact of COVID-19 Pandemic on Tourism: Perceptions from Bangladesh. SSRN Electronic Journal. https://doi.org/10.2139/ssrn.3632798

Dev, S. M., \& Sengupta, R. (2020). Covid-19: Impact on the Indian Economy. Working Paper 2020-013, (April), 41.

Devarakonda, S. (2016). Insurance Penetration and Economic Growth in India. FIIB Business Review, 5(3), 3-12. https://doi.org/10.1177/2455265820160301

Ehrlich, I., \& Becker, G. S. (1972). Market Insurance, Self-Insurance, and Self-Protection. Journal of Political Economy, 80(4), 623-648. https://doi.org/10.1086/259916 
Farooq, U., Nasir, A., Bilal, \& Quddoos, M. U. (2021). The impact of COVID-19 pandemic on abnormal returns of insurance firms: a cross-country evidence. Applied Economics, 53(31), 1-21 https://doi.org/10.1080/00036846.2021.1884839

Fernandes, N. (2020). Economic Effects of Coronavirus Outbreak (COVID-19) on the WorldEconomy. SSRN Electronic Journal. https://doi.org/10.2139/ssrn.3557504

Feyisa, H. L. (2020). The World Economy at COVID-19 Quarantine: Contemporary Review. International Journal of Economics, Finance and Management Sciences, 8(2), 63-74. https://doi.org/10.11648/j.ijefm.20200802.11

Gupta, M., Kumar, V., \& Singh, M. (2014). Creating Satisfied Employees Through Workplace Spirituality: A Study of the Private Insurance Sector in Punjab (India). Journal of Business Ethics, 122(1), 79-88. https://doi.org/10.1007/s10551-013-1756-5

Hutt, R. (2020). The economic effects of the coronavirus around the world | World Economic Forum. Accessed (Vol.22). Retrieved from https://www.weforum.org/agenda/2020/02/coronaviruseconomic-effects-global-economy-trade-travel

Islam, M. T., Talukder, A. K., Siddiqui, M. N., \& Islam, T. (2020). Tackling the COVID-19pandemic: The Bangladesh perspective. Journal of Public Health Research, 9(4), 389-397. https://doi.org/10.4081/jphr.2020.1794

Khan, N., Naushad, M., Fahad, S., Faisal, S., \& Muhammad, A. (2020). COVID-2019 and World Economy. SSRN Electronic Journal. https://doi.org/10.2139/ssrn.3566632

Khurshid, A., \& Khan, K. (2021). How COVID-19 shock will drive the economy and climate? Adatadriven approach to model and forecast. Environmental Science and Pollution Research, 28(3), 2948-2958. https://doi.org/10.1007/s11356-020-09734-9

Kirti, D., \& Shin, M. Y. (2020). Impact of COVID-19 on Insurers. International Monetary Fund Research, 1-11.

Kleinberg, B., van der Vegt, I., \& Mozes, M. (2020). Measuring Emotions in the COVID-19 Real World Worry Dataset. ArXiv:2004.04225 [Cs]. Retrieved from https://arxiv.org/abs/2004.04225

Kripa, D., \& Ajasllari, D. (2016). Factors Affecting the Profitability of Insurance Companies in Albania. European Journal of Multidisciplinary Studies, $1(1), \quad 352-360$. https://doi.org/10.26417/ejms.v1i1.p352-360

Larson, W. D., \& Sinclair, T. M. (2021). Nowcasting unemployment insurance claims in the time of COVID-19. International Journal of Forecasting. https://doi.org/10.1016/j.ijforecast.2021.01.001

Levantesi, S., \& Piscopo, G. (2020). Insurance Role for Handling the COVID-19 impact on Business and Society. Journal of Applied Management and Investments, 9(4), 183-191. Retrieved from http://www.jami.org.ua/Papers/JAMI_9_4_2020_183-191.pdf 
Loayza, N. V, \& Pennings, S. (2020). Macroeconomic Policy in the Time of COVID-19: A Primer for Developing Countries. World Bank Research and Policy Briefs, (147291). https://doi.org/10.1596/33540

Outreville, J. F. (1998). Theory and practice of insurance. Springer Science \& Business Media. Retrieved from https://books.google.com.bd/books?id=CoSYojFGf-cC

Ozili, P. K., \& Arun, T. (2020). Spillover of COVID-19: Impact on the Global Economy. SSRN Electronic Journal. https://doi.org/10.2139/ssrn.3562570

Parvathi, D. V, \& Lalitha, D. C. (2021). Impact of Covid-19 Pandemic on The Indian Insurance Sector. Perspectives on Business Management \& Economics, IV.

Puławska, K. (2021). Financial Stability of European Insurance Companies during the COVID-19 Pandemic. Journal of Risk and Financial Management, 14(6), 1-18. https://doi.org/10.3390/jrfm14060266

Ramasamy, D. (2020). Impact Analysis in Banking, Insurance and Financial services industry due to COVID-19 Pandemic. Pramana Research Journal, 10(8), 19-29. Retrieved from https://papers.ssrn.com/sol3/papers.cfm?abstract_id=3668165

Salehnia, N., Zabihi, S. M., \& Khashayar, S. (2020). The impact of COVID-19 Pandemic on Tourism Industry : A Statistical Review in European Countries. 2nd International Conference on Geography and Tourism Development and Sustainable Development 2020, (October), 1-11. https://doi.org/10.6084/m9.figshare.14528886.v2

Schoemaker, P. J. H., \& Kunreuther, H. C. (1979). An Experimental Study of Insurance Decisions. The Journal of Risk and Insurance, 46(6), 603-618. https://doi.org/10.2307/252533

Shammi, M., Bodrud-Doza, M., Islam, A. R. M. T., \& Rahman, M. M. (2020). Strategic assessment of COVID-19 pandemic in Bangladesh: comparative lockdown scenario analysis, public perception, and management for sustainability. Environment, Development and Sustainability, 23(4),61486191. https://doi.org/10.1007/s10668-020-00867-y

Shi, Y., Wang, G., Cai, X. P., Deng, J. W., Zheng, L., Zhu, H. H., .. Chen, Z. (2020). An overview of COVID-19. Journal of Zhejiang University-SCIENCE B, 21(5), 343-360. https://doi.org/10.1631/jzus.b2000083

Spence, M., \& Zeckhaser, R. (1978). Insurance, Information, and Individual Action. Uncertainty in Economics, 61(2), 333-343. https://doi.org/10.1016/b978-0-12-214850-7.50027-9

Stojkoski, V., Jolakoski, P., \& Ivanovski, I. (2020). The short-run impact of COVID-19 on theactivity in the insurance industry in the Republic of North Macedonia. ArXiv. 
Uddin, M. N., Majumder, M. A., \& Chowdhury, M. M. (2014). Insurance Business and Risk Management: An Empirical Study on General Insurance Companies in Bangladesh. Indonesian Management and Accounting Research, 13(2), 62-81.

Wang, Y., Zhang, D., Xiaoquan, W., \& Fu, Q. (2020). How does COVID-19 affect China's insurance market? Emerging Markets Finance and Trade, 56(10), 2350-2362.

Werner, W. J. (2009). Micro-insurance in Bangladesh: Risk protection for the poor? Journal of Health, Population and Nutrition, 27(4), 563-573. https://doi.org/10.3329/jhpn.v27i4.3402

WHO. (2021). WHO Coronavirus (COVID-19) Dashboard. WHO Coronavirus (COVID-19) Dashboard with Vaccination Data. Who. Retrieved from https://covid19.who.int

Worku, A., \& Mersha, D. (2020). The Effect of COVID -19 on Insurance Industry in Ethiopia. Horn of Africa Journal of Business and Economics (HAJBE), 39-44.

Xia, Y., Li, S., \& Meng, K. (2020). The Impact of the COVID-19 on the Insurance Industry in China. Frontiers in Economics and Management, $1(12), \quad 28-44$. https://doi.org/10.6981/FEM.202012_1(12).0006

Ye, R., An, N., Xie, Y., Luo, K., \& Lin, Y. (2021). An Empirical Study on the Equity Performance of China's Health Insurance Companies during the COVID-19 Pandemic-Based on Cases of Dominant Listed Companies. Front Public Health, 9. Retrieved from https://www.ncbi.nlm.nih.gov/pmc/articles/PMC8141801

Zhang, D., Hu, M., \& Ji, Q. (2020). Financial markets under the global pandemic of COVID-19. Finance Research Letters, 36,101528. https://doi.org/10.1016/j.frl.2020.10152

\section{Copyrights}

Copyright for this article is retained by the author(s), with first publication rights granted to the journal. This is an open-access article distributed under the terms and conditions of the Creative Commons Attribution license (http://creativecommons.org/licenses/by/4.0) 